\title{
I Speak for Myself: American Women on Being Muslim
}

Eds. Maria M. Ebrahimji and Zahra T. Suratwala

Ashland, OR: White Cloud Press, 2011, pbk. 236 pages.

The anthology, I Speak for Myself, is the first in a series of books that allow Muslims to write about themselves. This volume is about American women describing their experiences of being a Muslima - with one from a man, and further volumes in the series will focus on the American Muslim male perspective and voices from the Arab Spring. Like most anthologies, the submissions are uneven, and with forty essays, there are more than a few poor essays. The editors indicate that they wanted the authors to write essays that reflected their comfortable relationship to country and faith, but otherwise they left the theme open.

Although the editors seem to have hoped for a diverse outpouring of essays, and there is a great deal of diversity, there are certain common themes. Most notably were a series of essays by women who only talked about the hijab, as though that was their identity. These essays were fairly similar to one another, which may be the result of the short length of these pieces. There is value in keeping the contributions brief, as stories move along and ideas develop quickly, but is a problem when several people write on the same issue.

Despite this general criticism, this book is a natural fit for any course on Islam in America, gender and religion, or even as an introduction to Islam course. There are some absolutely delightful and fascinating essays in this collection. The strongest ones dealt with the implicit nature of being Muslim and American. Rather than discussing either or both identifications, authors simply talked about their lives. Following are several examples of these types of essays. 
Fatemeh Fakhraie's "Roots" deals with her current relationships with her parents. She wonders if her mother feels she has to bribe her to spend time with her by taking her shopping and to nice restaurants. That immediate hook seems like one extended to anyone who is close to her family, but not living near home. She then expands her vision, talking about how she feels she has outgrown her home, but that she is still her parents' child. She shares her father's temper and laugh, and the strength of her mother. She worries about the death of her parents. It is a sweet story, not only of an author who is Muslim and American, but as one who is a daughter.

Maria Ebrahimji, one of the editors of the volume, has an essay that speaks to a spiritual quest and her conceptions of taqwa (righteousness). It is embedded in a transnational search for finding religious meaning, but also grounded in her family and home. "Unwelcome Change," by Mona Rajab is one of the richer essays on the hijab, dealing with her family's negative reaction to her wearing the headscarf. Hadia Mubarak's "Crossroads" also deals with the hijab, but compares her experiences wearing it in Jordan and in the United States. To some readers, I'm sure it will be a surprise to find out that she is in the minority when in Jordan, but in the majority in her community in the United States. Little asides like this provide a contrast and make this volume a rich source as teaching material. The theme of being defined by others is developed in essays by Amina Choueiki and Amany Ezeldin, both of whom struggle with being too American in one context and not American enough in another - but in very different ways.

Being a female high school basketball player during Ramadan is no easy task for Dewnya Bakri-Bazzi. However, she maintains the fast, and uses it as an opportunity to talk about her faith to her teammates. Although she does slip into the formulation that somehow Islam and peace are synonymous (62), the strength of the essay is that it shows the impact of shared experiences. Zaynab Alwan's essay of being in high school, when the 2003 invasion of Iraq occurred, is a powerful reminder of the need to communicate, especially during times of loss and crisis. Alwan is of Iraqi descent and is deeply concerned about the invasion. She feels isolated until one of her teachers says she is worried too, because her son is in the army. Rather than looking at each other as potential adversaries, they hope for peace together.

Another difficult high school experience is shared by Arshiya Saiyed, who wanted to remove prayer from her graduation ceremony. Many people believed that she did so because as a Muslim she did not want a Christcentric prayer. The Islamophobes called her a jihadist, and Muslims called 
her a bad Muslim for not demanding an "Islamic" prayer or the covering on her head. However, her rationale was embedded in the First Amendment. She believed that the prayer violated American values.

There are also essays that are so well-wrought, that I would do them a disservice by attempting to summarize them. Sarah Azad talks about one of her days as an $\mathrm{Ob} / \mathrm{Gyn}$ when she has to go to the airport to pick-up her sister. Ruqayya Gibson gives us her life story in a way that highlights ideas of service and sacrifice. From Saliqa Khan, we hear of what Islam and marriage mean to her. All of these essays may talk about Islam, but it is not their focus. These are stories of life in America.

Part of American life is racism, and the hidden face of racism comes out clearly in Sevim Kalyoncu's essay, "Learning Tolerance," in which she is silenced by those who do not wish to hear her. However, two other women in the collection use their voices to great effect. Rashida Tlaib tells of her engagement with the political process to become the first Muslim woman elected to the Michigan legislature. While the essay could serve as a campaign ad, it is also very human, because she talks about her community, not just herself. The collection ends with a piece by Kameelah Rasheed, who talks about the mastery of words to declare her own of self. And she breaks down the categories by which she is defined and remakes them to define herself.

This last essay closes out the collection nicely, as it helps to see the women represented as speaking for themselves. One striking part of the collection was how few essays dealt with gender. There was a naturalness to being women, but the subtext of gender was ever present. The book offers a wide variety of readings that can be used across courses and disciplines. Because of the brevity of each piece, the things that are not said can be as useful as the things that are. While I suspect that many essays will be used in introductory courses, there is some rich material that can be mined for upper-level courses as well. 